\title{
Human Dignity in Law - A Case Study of the Polish Legal System
}

\begin{abstract}
Human dignity is one of the most fundamental ideas in the entire international human rights system. As from the Universal Declaration of Human Rights, in 1948, the concept of the human dignity become used as a tool to protect the basic needs of humans. The other formal instruments of international human rights also make reference to dignity. Whereas international law widely accepted the inherence of dignity, controversies still arise around the source of the dignity. Polish lawmakers, on the other hand, have no doubt about the fact the concept of dignity comes from natural law. Poland, in her Constitution, refers to the teaching of John Paul II about the source, value and meaning of human dignity. There is no doubt that concept of human dignity, even when it is controversial, is the most widely accepted by all religions and political society in the world.
\end{abstract}

\section{Keywords}

Dignity, international law, Polish Constitution, Universal Declaration of Human Rights, International Covenant on Civil and Political Rights.

The dignity of the human being is the cornerstone of all laws, rights and freedoms, which touch the sphere of human existence. In his letter to the Secretary General of the IV Conference of the United Nations Concerning the Woman, John Paul II had stressed that the human beings are at the centre of the natural order, and their 
dignity is the source of rights and freedom. ${ }^{1}$ This Polish Pope was convinced that the dignity of the human being should be the first and the only one reflection the all laws. What he was saying is that, in each case, when the lawmaker has human dignity as a priority, as a main concern, in the process of law creation, such law cannot be harmful for the human being. Dignity is coming from the natural law and natural law is directly granted us from the God himself because, God created man in His image. ${ }^{2}$

"Today the promotion of human rights is central to the commitment of the European Union to advance the dignity of the person, both within the Union and in its relations with other countries." 3 These words of Pope Francis to the representatives of the European Union governing body mark two important lines: first duty of all governments who should always put human dignity as the focus of every action. The second most important conclusion coming from the Pope's speech is the statement that human dignity is the source of human rights. So the Pope, in this short sentence, is giving the answer to the two most important questions of the modern legal word: where is the source of human rights? Who is responsible for the respectfulness and protection of human rights? The answers are simple: the dignity of a person is central to the concept of human rights and the governments are responsible for its protection. However, when it comes to the conflict between faith and science, there is difficult to choose the winer. The question here does not exist on the level of terminology. There is no such conflict there. The conflict arises in the level of content. Conflict also appears in the sphere of law when it comes to discussion about the source of dignity ${ }^{4}$. Both Popes teach that the dignity of human being comes from the natural law, however there are some religions, scholars and lawyers who will deny such an approach to dignity. However, they forget, that in each state, can be recognised two different legal systems: custom law and positive law. The source of customs

${ }^{1}$ John Paul II, List do Sekretarz Generalnej Gertrude Mongella, IV światowej konferencji ONZ poświęconej kobiecie, Watykan, 26 maja 1995 r., http://nauczaniejp2.pl/dokumenty (06.09.2016).

${ }^{2}$ Jan Paweł II, Ecclesia in America, w: Dzieła zebrane, red. P. Ptasznik, t. 2: Adhortacje, Kraków 2006, pp. 707-709.

${ }^{3}$ Pope Francis addresses the European Parliament in Strasbourg, on Nov. 25, 2014, http:// www.catholicnewsagency.com/news/pope-tells-haggard-europe-that-human-dignity-is-keyto-renewal-89576/ (06.09.2016).

4 T. Pabian, Some remarks on the conflict between faith and science, "The Person and the Challenges" 6 (2016) 1, p. 67-68. 
is natural law, and they cannot deny the existence of the customary legal system. On the other hand international law is trying to not give such straight answers but allows other interpretations. The other problem which arises is whether dignity is so commonly adopted whereas there is no conflict what "dignity" means the conflict arises what is the common understanding of the dignity.

\section{The Meaning of the word 'dignity'}

The English word "dignity" has its origins in the Latin word "dignitas" which means 'respect' or 'worthy of respect.' Romans used this word only in the context of human, so it was a human attribute. ${ }^{5}$ In the Bible, this word is used in two contexts: first for God and angels, and second for the people. ${ }^{6}$

The problem which the word "dignity" causes in International Law is that in some languages there is no equivalent of this word. Thus, it becomes difficult to adapt the European idea of dignity to a society, which does not follow exactly the same values and ideas. ${ }^{7}$ However, since the language used in international law is generally English, the interpretation of the local language is up to each state. There is another problem in the sphere of International Law on what dignity really means?

\section{Dignity in the international law}

The word 'dignity' now has a legal meaning, and is used by lawmakers as a transcended undefined idea. The lack of a universal definition of 'dignity' causes problems in the wide cross-cultural use of the term. However by the wide acceptance of two major international legal acts the idea of dignity was also adopted by the international society. So it is important to look at these two documents and tried to understand how 'dignity' is explained in them.

${ }^{5}$ M. Chmaj, Wolności i prawa człowieka w Konstytucji Rzeczypospolitej Polskiej, Warszawa 2008, p. 28-29.

“ M. Novak, Godność człowieka, wolność osoby, „Przegląd Powszechny” (1998) nr 1, p. $25-26$.

7 C. Baker, Dignity in International Human Rights law, published in "International Write for Rights Movement” (2011), p. 10-11. 
The first legal act (of more broader range than any other acts) is The Universal Declaration of Human Rights, proclaimed by the United Nations General Assembly in Paris on 10 December 1948 General Assembly resolution 217(III). ${ }^{8}$ The Declaration begins with the following words: "whereas recognition of the inherent dignity and of the equal and inalienable rights of all members of the human family is the foundation of freedom, justice and peace in the world ....' 9 There are also other references to the dignity in the Declaration in article 1 , article 22 and article 23. Article 1 is especially important because it refers to all humans who from the day they born are free and equal in dignity. ${ }^{10}$ So the dignity is the foundation of rights indicated in the Declaration. The Declaration, in descriptive ways, also tries to define 'dignity' as inherent and of equal human worth. ${ }^{11}$ The idea of 'human dignity' in the Declaration serves the basis for the other principles of human rights. It can be also noted that there is no clear and univocal definition of dignity in the Declaration. The latter allows for different multiple understandings with varied historical backgrounds but only in the scope of the meaning of the Declaration. The Polish scholar Wiktor Osiatyński argues that the idea of dignity as presented in the Declaration is necessary to protect the social and personal rights. He also contend that dignity is a common ground which various philosophers can meet and reconciled. ${ }^{12}$ So, the legal approach to dignity as presented in the Declaration is accepted by the major states.

The other international legal act in which 'dignity' is defined is the International Covenant on Civil and Political Rights ${ }^{13}$ adopted and open for signature and ratification by the United Nations General Assembly on 16 December 1966. The Covenant in the second line of the preamble evokes dignity; describes it as inherent, and an equal and inalienable right. Also the Covenant directly

8 The Universal Declaration of Human Rights, United Nations General Assembly in Paris on 10 December 1948 General Assembly resolution 217 (III).

9 IBID

10 "All human beings are born free and equal in dignity and rights. They are endowed with reason and conscience and should act towards one another in a spirit of brotherhood." The Universal Declaration of Human Rights, United Nations General Assembly in Paris on 10 December 1948 General Assembly resolution 217 (III).

${ }^{11}$ P. G. Carozza, Human Dignity and Judicial Interpretation of Human Rights: A Reply, “The European Journal of International Law” Vol. 19 no. 5, p. 932-935.

12 W. Osiatyński, Human Rights and their Limits, Budaphest 2009, p. 129-131.

13 Międzynarodowy Pakt Praw Obywatelskich i Politycznych otwarty do podpisu w Nowym Jorku dnia 19 grudnia 1966 r., DZ. U. 1977 nr 38, poz. 167. 
states that rights like: freedom, justice and peace are derived directly from human dignity. ${ }^{14}$ The third time in which dignity appears is in article 10 when it ascertains that each person who is arrested, or in another way, deprived from his/her freedom, should be treated with dignity ${ }^{15}$. However there is no more said about what this exactly means. The Covenant unlike the Declaration is not analysing the scopes of dignity but only affirms that State action should be focused on the protection of the human dignity.

To summarise it can be concluded that in these two international documents dignity is considered as the foundation and as a source of all rights and freedom, which, through these Acts, are granted to all humans in the world. In both Acts there is no question about the source of the dignity. Dignity is perceived as inherent in every human being and it is not dependant on ability and merit Dignity is a fact, and states should do whatever is in their power to protect it.

\section{Dignity in the Polish legal order}

The Polish legal system, when it comes to the defining 'dignity'. is one of the few legal systems where dignity plays so important a role. Besides, Polish lawmakers decided not only define dignity but also very clearly state where the source of dignity lays. The word 'dignity' appears three times in the Constitution of the Republic of Poland (further Constitution) of $2^{\text {nd }}$ April 1997. The first time is in preamble, when we can read that: "we call upon all those who will apply this Constitution for the good of the Third Republic to do so paying respect to the inherent dignity of the person, his or her right to freedom, the obligation of solidarity with others, and respect for these principles as the unshakeable foundation of the Republic of Poland." ${ }^{16}$ Let us stop for a moment, to make

$14 \ldots . .$. and of the equal and inalienable rights of all members of the human family is the foundation of freedom, justice and peace in the world, Recognizing that these rights derive from the inherent dignity of the human person", Międzynarodowy Pakt Praw Obywatelskich i Politycznych otwarty do podpisu w Nowym Jorku dnia 19 grudnia 1966 r., DZ. U. 1977 nr 38, poz. 167.

15 „All persons deprived of their liberty shall be treated with humanity and with respect for the inherent dignity of the human person", Międzynarodowy Pakt Praw Obywatelskich i Politycznych otwarty do podpisu w Nowym Jorku dnia 19 grudnia 1966 r., DZ. U. 1977 nr 38, poz. 167.

16 Wszystkich, którzy dla dobra Trzeciej Rzeczypospolitej tę Konstytucję będą stosowali, wzywamy, aby czynili to, dbając o zachowanie przyrodzonej godności człowieka, jego prawa do 
a short analysis of these words. First of all, their place at the end of the preamble is like a summary of all reasons and values, which lay as the foundation in the creation of the constitution. Secondly, the words, which are used in this sentence, are like a vocation: "We call". So the constitution writers are appealing, or obliging, all people who would be enforce the Constitution to do this in the light of human dignity. This dignity is defined as inborn and independent from ability or merit. The next instance is when 'dignity' is put in this same line with the freedom and solidarity and these three are the foundation of the Polish state. $^{17}$

Next there is Article 30 of the Constitution, which is placed in Chapter II "The Freedoms, Rights and Obligations of Persons and Citizens" under the subtitle 'General Principles'. The first general principle is dignity: as an inherent and an inalienable essence of human being. Dignity constitutes a source of all freedom and rights of any person and citizen. Dignity is inviolable, which means that it cannot be relinquished even by the act of freewill man. ${ }^{18}$ Being the first and the most important general principle dignity is defined here by the description of its characteristics. ${ }^{19}$ According to the Constitution dignity belongs to each human, is a personal and indefeasible right rooted in Constitution and the state is responsible for its protection. ${ }^{20}$ Until now, it can be said that for the Polish lawmaker dignity is the cornerstone of the Polish state. It, is the source of all freedom and rights and is rooted in natural law.

wolności i obowiązku solidarności z innymi, a poszanowanie tych zasad mieli za niewzruszoną podstawę Rzeczypospolitej Polskiej. The Constitution of the Republic of Poland of 2nd April, 1997, as published DZ. U. nr. 78, poz. 483, as amended; the translation of the Constitution is taken from the official web side of Polish Sejm, http://www.sejm.gov.pl/prawo/konst/angielski/ kon1.htm (19.02.2016).

17 Wyrok TK z dnia 29 kwietnia 2003 r., sygn. akt SK 24/02, OTK ZU Nr 4/A/2003, poz. 33.

18 "The inherent and inalienable dignity of the person shall constitute a source of freedoms and rights of persons and citizens. It shall be inviolable. The respect and protection thereof shall be the obligation of public authorities", The Constitution of the Republic of Poland of 2nd April, 1997, as published DZ. U. nr. 78, poz. 483, as amended; the translation of the Constitution is taken from the official web side of Polish Sejm, http://www.sejm.gov.pl/prawo/konst/angielski/ kon1.htm (19.02.2016).

19 P. Zientkowski, i inni, W poszukiwaniu paradygmatu wartości, w: Z problemów bezpieczeństwa: Prawa człowieka, red. T. Jasudowicz i inni, Zeszyt Naukowy nr 4/2b/2012, Chojnice, p. $48-49$.

${ }^{20}$ M. Chmaj, Wolności i prawa człowieka w Konstytucji Rzeczypospolitej Polskiej, Warszawa 2008, p. 27-31. 
The third place in constitution where dignity is mentioned is Article 233. The section in which this article is placed is in the section with the title: Extraordinary Measures. When the extraordinary measures are introduced, some rights and freedoms can be suspended. However there are some, which, in any circumstance, cannot not be suspended, and Article 233 of the Constitution contains an exhaustive list of these freedoms. The first one mentioned is dignity. ${ }^{21}$ This is only a repetition of the previous regulation of the inalienable dignity regardless of any human action.

The existence of dignity in the Polish legal system as a rule of law, as a cornerstone of the Polish state is the most important assumption, which is founded on the Constitution. This rule was secure in the Polish legal system by the Constitutional Tribunal ${ }^{22}$ who, in one of his first ruling in 1999, clearly declared that: dignity is a fundamental rule in the Polish legal system ${ }^{23}$ and can be identified as the sole rule based on the meaning of Article 30 of the Constitution. ${ }^{24}$ This statement was lately upheld by the Tribunal ruling, which, for example, in its sentence granted on 5 march 2003 argued that dignity has transcendental value, and is primary to the other rights and human freedom, especially since dignity is the source of these rights and freedom. According to the Tribunal dignity is innate to each human and cannot be repudiated by

21 "The statute specifying the scope of limitation of the freedoms and rights of persons and citizens in times of martial law and states of emergency shall not limit the freedoms and rights specified in Article 30 (the dignity of the person), Article 34 and Article 36 (citizenship), Article 38 (protection of life), Article 39, Article 40 and Article 41, para.4 (humane treatment), Article 42 (ascription of criminal responsibility), Article 45 (access to a court), Article 47 (personal rights), Article 53 (conscience and religion), Article 63 (petitions), as well as Article 48 and Article 72 (family and children)". The Constitution of the Republic of Poland of 2nd April, 1997, as published DZ. U. nr. 78, poz. 483, as amended; the translation of the Constitution is taken from the official web side of Polish Sejm, http://www.sejm.gov.pl/prawo/konst/angielski/ kon1.htm (19.02.2016).

22 The Constitutional Tribunal is an independent constitutional organ of the State which main competence is the review of norms, i.e. adjudicating on hierarchical (vertical) conformity of normative acts of lower rank to the normative acts (legal norms) of higher rank and eliminating provisions adjudicated as unconstitutional from the system of law in force. Trybunat Konstytucyjny, http://trybunal.gov.pl/en (02.09.2016).

${ }^{23}$ Wyrok Trybunału Konstytucyjnego, z dnia 23 marca 1999 r., sygn. K 2/98, OTK ZU Nr 3(25)/1999, poz. 38.

${ }^{24}$ Wyrok TK z dnia 15 października 2002 r., sygn. akt SK 6/02, OTK ZU Nr 5/A/2002, poz. 65. 
any human action. ${ }^{25}$ The Tribunal broadened the Constitutional definition of dignity by clarifying the function which dignity has in the Polish legal system. First, dignity is the link between the natural legal order and human legal order. Secondly, it is the sole source of the interpretation of the Constitution, and jurists who interpret the Constitution are bound by the Constitutional definition of dignity. This same attitude must be used when the Constitution is enforced. Finally, dignity is a link between civil law and the system of human rights and freedom. ${ }^{26}$

To summarize, in the Polish legal system human dignity plays the most important role among other rules. For Polish lawmakers human dignity has two aspects: first of all as inviolable,: nobody can be deprived from his/her dignity in any circumstance. This is something that is personal and is connected with the fact of being human. However, there is another aspect of the dignity, because as the Constitution Tribunal declared: at some point dignity is perceived as a right which can be harmed by human action. ${ }^{27}$

\section{Dignity as the foundation of Human Rights}

The Universal Declaration on Human Rights, cited above, not only introduced the legal meaning of the dignity but also created the legal frame for the judges and litigator to expand on the meaning of the word 'dignity'. It also provides the convenient language for the adaptation of human rights guarantees. The concept of human dignity play an important role in the development of human rights adjudication. ${ }^{28}$ This same interpretation also comes from the Constitutional

25 “...godność człowieka jako wartość transcendentna, pierwotna wobec innych praw i wolności człowieka (dla których jest źródłem), przyrodzona i niezbywalna - towarzyszy człowiekowi zawsze i nie może być naruszona ani przez prawodawcę, ani przez określone czyny innych podmiotów. W tym znaczeniu człowiek zawsze zachowuje godność i żadne zachowania nie mogą go tej godności pozbawić, ani jej naruszyć." Wyrok Trybunału Konstytucyjnego z dnia 5 marca 2003 r. sygn. akt K 7/01.

${ }^{26}$ Wyrok TK z dnia 15 października 2002 r., sygn. akt. SK 6/02, OTK ZU Nr 5/A/2002, poz. 65.

${ }^{27}$ M. Tushnet, T. Fleiner, C. Saunders, Routledge Handbook of Constitutional Law, Abingon 2013, p. 201-204.

${ }^{28} \mathrm{Ch}$. McCrudde, Human Dignity and Judicial Interpretation of Human Rights, "Eur J Int Law" (2008) 19 (4), p. 655-724 (doi: 10.1093/ejil/chn043). 
Tribunal, which distinguishes between two dimensions of human dignity. The first dimension was broadly elaborated above. On one hand the dignity cannot be granted by any human action, so it not comes from the state, government or international society. If the dignity cannot be granted it cannot be take away. ${ }^{29}$ The other dimension of dignity is more like personal rights, the sphere of rights which define the existence of the human being. ${ }^{30}$ This dimensions of dignity identify humans in society and acknowledge the respect which each member of society possesses. Understanding dignity in this way leads to the conclusion that it can be breached by the acts of other humans. If such a violation occurs it should be immediately repaid and damage compensated for. In general, such situations of injustice should be judge by the moral and social code, which exist in particular society. ${ }^{31}$ The modern approach to human rights is rooted in the idea of human dignity and human rights law relies on the idea of human dignity. As commentaries point out: human dignity has formed, the meaning and use of principles in international human rights law. It has a foundational and structural place in the acknowledgement it is given in the canon of human rights treaties. ${ }^{32}$

\section{Bibliography}

\section{Literature}

Baker C., "Dignity in International Human Rights Law”, International Write for Rights Movement (2011).

Carozza P. G., "Human Dignity and Judicial Interpretation of Human Rights: A Reply", The European Journal of International Law, vol. 19 no. 5.

Chmaj M., Wolności i prawa człowieka w Konstytucji Rzeczypospolitej Polskiej, Warszawa 2008.

Jan Paweł II, List do Sekretarz Generalnej Gertrude Mongella, IV światowej konferencji ONZ poświęconej kobiecie, Watykan, 26 maja 1995 r., http://nauczaniejp2.pl/ dokumenty (06.09.2016).

29 Wyrok TK z dnia 4 kwietnia 2001 r., sygn. akt K 11/00, OTK ZU Nr 3(41)/2001, poz. 54.

30 Wyrok TK z dnia 5 marca 2003 r., sygn. akt K 7/01, OTK ZU Nr 3/A/2003, poz. 19.

31 Wyrok Trybunatu Konstytucyjnego z dnia 7 lutego 2005 r. sygn. akt SK 49/03.

32 D. Shleton, The Oxford Handbook of International Human Rights Law, Oxford 2013, p. 345-346. 
Jan Paweł II, Ecclesia in America, w: Dzieła zebrane, red. P. Ptasznik, t. 2: Adhortacje, Kraków 2006.

McCrudde Ch., Human Dignity and Judicial Interpretation of Human Rights, "Eur J Int Law" (2008) 19 (4), p. 655-724 (doi: 10.1093/ejil/chn043).

Osiatyński W., Human Rights and their Limits, Budapest 2009.

Novak M., Godność człowieka, wolność osoby, „Przegląd Powszechny” (1998) nr 1.

Pope Francis, Address to the European Parliament in Strasbourg, on Nov. 25, 2014, http://www.catholicnewsagency.com/news/pope-tells-haggard-europe-that-humandignity-is-key-to-renewal-89576/ (06.09.2016).

Pabjan T., Some remarks on the conflict between faith and science, "The Person and the Challenges" 6 (2016) 1.

Shleton D., The Oxford Handbook of International Human Rights Law, Oxford 2013.

Trybunat Konstytucyjny, http://trybunal.gov.pl/en (02.09.2016).

Tushnet M., Fleiner T., Saunders C., Routledge Handbook of Constitutional Law, Abingon 2013.

Zientkowski P., i inni, W poszukiwaniu paradygmatu wartości, w: Z problemów bezpieczeństwa: Prawa człowieka, red. T. Jasudowicz i inni, „Zeszyt Naukowy” nr 4/2b/2012, Chojnice.

\section{Legal Acts}

The Universal Declaration of Human Rights, United Nations General Assembly in Paris on 10 December 1948 General Assembly resolution 217 (III).

Międzynarodowy Pakt Praw Obywatelskich i Politycznych otwarty do podpisu w Nowym Jorku dnia 19 grudnia 1966 r., DZ. U. 1977 nr 38 poz. 167.

The Constitution of the Republic of Poland of 2nd April, 1997, as published DZ. U. nr. 78, poz. 483, as amended; the translation of the Constitution is taken from the official web side of Polish Sejm, http://www.sejm.gov.pl/prawo/konst/angielski/kon1.htm (19.02.2016).

\section{Judgements}

Wyrok Trybunału Konstytucyjnego, z dnia 23 marca 1999 r., sygn. K 2/98, OTK ZU Nr 3(25)/1999, poz. 38.

Wyrok TK z dnia 15 października 2002 r., sygn. akt SK 6/02, OTK ZU Nr 5/A/2002, poz. 65. Wyrok TK z dnia 4 kwietnia 2001 r., sygn. akt K 11/00, OTK ZU Nr 3(41)/2001, poz. 54. Wyrok TK z dnia 29 kwietnia 2003 r., sygn. akt SK 24/02, OTK ZU Nr 4/A/2003, poz. 33. Wyrok TK z dnia 5 marca 2003 r., sygn. akt K 7/01, OTK ZU Nr 3/A/2003, poz. 19. Wyrok Trybunału Konstytucyjnego z dnia 7 lutego 2005 r. sygn. akt SK 49/03. 